\title{
Noncovalent Complexes Formed between Metal-Substituted Polyoxometalates and Hen Egg White Lysozyme
}

\author{
Laurens Vandebroek, ${ }^{[a]}$ Yentl Mampaey, ${ }^{[a]}$ Svetlana Antonyuk, ${ }^{[b]}$ Luc Van Meervelt, ${ }^{[a]}$ and \\ Tatjana N. Parac-Vogt*[a]
}

6 Abstract: Four Wells-Dawson type metal-substituted polyoxometalates (MSPs), 1:2 $\mathrm{Zr}^{\mathrm{IV}}$-Wells-Dawson $\left[\mathrm{Zr}^{\mathrm{IV}}\left(\alpha_{2}-\mathrm{P}_{2} \mathrm{~W}_{17} \mathrm{O}_{61}\right)\right]^{8-}$ (1), 1:1 Co"l-Wells-Dawson $\left[\mathrm{Co}^{\prime \prime}\left(\alpha_{2}-\mathrm{P}_{2} \mathrm{~W}_{17} \mathrm{O}_{61}\right)\right]^{10-}(\mathbf{2}), 1: 1 \quad \mathrm{Ni}^{\prime \prime}-$ Wells-Dawson [Nill $\left.\left(\alpha_{2}-\mathrm{P}_{2} \mathrm{~W}_{17} \mathrm{O}_{61}\right)\right]^{10-}(\mathbf{3})$ and 1:1 Cu"-Wells-Dawson $\left[\mathrm{Cu}^{\prime \prime}\left(\alpha_{2}-\mathrm{P}_{2} \mathrm{~W}_{17} \mathrm{O}_{61}\right)\right]^{10-}(4)$, which differ in the nature of the 11 imbedded metal ion, were examined in co-crystallization experiments with a protein Hen Egg White Lysozyme (HEWL). Single crystal X-ray structures of four noncovalent complexes between POMs and HEWL have been determined, and the influence of the type of substituted metal on the mode of POM binding to a protein was investigated. All crystal structures exhibited a high 16 degree of similarity, suggesting that the interaction is largely independent on the nature of substituted metal within the same polyoxometalate (POM) archetype. The main driving force for the formation of the noncovalent complex is electrostatic attraction between POM and HEWL surface regions. Stabilization is further provided by direct and water mediated hydrogen bonding between terminal oxygen atoms of the POM framework and flexible HEWL residues.

\section{Introduction}

26 Polyoxometalates (POMs) are transition metal clusters, where the transition metal most commonly exists in their highest oxidation state. POMs occur as many geometrical archetypes, sizes and can be comprised of a multitude of elements. This variable nature allows for POMs to possess tunable properties, such as

31 redox potential or charge density. While this class of inorganic molecules has long been revered for their applications in chemical catalysis and material engineering, more recent explorations have indicated that polyoxometalates can have biological applications as well. ${ }^{[1-4]} \mathrm{A}$ series of cell-culture studies provided

36 evidence that many POMs possess an antibacterial and antiviral activity. ${ }^{[5,6]}$ Although the exact mechanism for such activity is not known, it has been mainly attributed to electrostatic interactions between the highly negatively charged POMs and the positively charged regions of proteins or biological mem-

41 branes. $^{[7-9]}$ Additionally, recent findings showed that both hydrogen bonds and covalent bonds may also contribute to stabilizing the POM-protein complex. ${ }^{[10]}$ An in-situ-formed Anderson-Evans POM was crystallized in a protein environment, covalently bound to a glutamate side chain and stabilized 46 through hydrogen bonds. ${ }^{[10]}$

[a] Department of Chemistry, KU Leuven,

Celestijnenlaan 200F box 2404, 3001 Heverlee (Leuven), Belgium

E-mail: tatjana.vogt@kuleuven.be chem.kuleuven.be/lbc/

1( $<=$ Author: please insert the URL of your group or institute))

[b] Institute of Integrative Biology, University of Liverpool, Life Sciences Building, Crown Street, Liverpool L69 7ZB, UK

Supporting information and $O R C I D(s)$ from the author(s) for this article are available on the WWW under https://doi.org/10.1002/ejic.201801113.
The fact that POMs are capable of binding to proteins makes them potential candidates for applications in biocatalysis. Substitution of one POM addenda atoms with a Lewis acid metal, results in a POM that exhibit catalytic activity towards the hydrolysis of peptide bond in proteins. In such systems the 51 POM selectively binds to protein surface, after which the Lewis acid metal activates the peptide bond, resulting in its hydrolysis. ${ }^{[11-14]}$ The hydrolysis is remarkably selective, as negatively charged POMs exhibit strong affinity towards the positive patches on the protein surface.

A number of spectroscopic studies have been conducted between POMs and different proteins, such as Hen Egg White Lysozyme (HEWL), ${ }^{[15]}$ Human/Bovine Serum Albumin, ${ }^{[7,16-19]}$ Horse Heart Myoglobin, ${ }^{[20]}$ among others, which support the electrostatic mechanism. Furthermore, molecular dynamics cal- 61 culations involving metal-substituted POMs (MSPs) and HEWL also indicate that proteins interact with POMs mainly via electrostatic and hydrogen-bonding interactions, involving positively charged and polar uncharged amino acid residues. ${ }^{[8]} \mathrm{Ad}-$ ditionally, crystallography has proven to provide valuable infor- 66 mation on the interactions between POMs and proteins by allowing every occurring type of interaction to be mapped. Moreover, POMs have been shown to lower disorder at flexible regions of proteins due to their rigid framework, resulting in facilitated crystal growth. ${ }^{[21,22]}$ For example, POMs facilitated the 71 small ribosomal subunit crystallization, while the heavy atoms in their structure were used for phasing. ${ }^{[23,24]}$ This possibility for experimental phasing is of great use in the field of macromolecular crystallography. POMs are comprised of a large number of heavy atoms and the strong anomalous scattering caused by 76 the $\mathrm{W}$ or Mo atoms largely facilitates the experimental phasing of proteins. Due to these properties, currently over 30 structures 
of proteins can be found in the Protein Data Bank (PDB) that contain a certain type of polyoxometalate. These structures are

81 a valuable and reliable source of information regarding interactions on a near-atomic level and have contributed to the better understanding of the interactions between POMs and proteins. ${ }^{[21]}$

While the molecular interactions between polyoxometalate

86 framework and proteins have been relatively well understood, the question of how different modifications of the POMs structure affect their binding to the protein have been virtually unexplored. In case of Zr-substituted POMs the experimental and theoretical studies suggest that the $\mathrm{Zr}^{\mathrm{IV}}$ ion interacts with the

91 peptide bond by binding to the carbonyl oxygen, which makes the carbonyl carbon more susceptible to nucleophilic attack of a water molecule. ${ }^{[25-28]}$ This implies that dimeric 1:2 $\left[\operatorname{Zr}\left(\alpha_{2}{ }^{-}\right.\right.$ $\left.\left.\mathrm{P}_{2} \mathrm{~W}_{17} \mathrm{O}_{61}\right)_{2}\right]^{16-}$ needs to dissociate into catalytically active monomeric 1:1 complex $\left[\mathrm{Zr}^{\mathrm{IV}}\left(\alpha_{2}-\mathrm{P}_{2} \mathrm{~W}_{17} \mathrm{O}_{61}\right)\right]^{8-}$ which has more

96 open sites for the interaction with the peptide bond. The cocrystal structures of $\mathrm{Zr}^{\mathrm{l}}$-substituted Keggin and $\mathrm{Hf}^{\mathrm{V}}$-substituted Wells-Dawson POM bound to HEWL ${ }^{[29,30]}$ have shown that although HEWL was mixed with the hydrolytically inactive 1:2 forms of the POM, the resulting co-crystals contained only the

101 monomeric 1:1 forms. These crystal structures provided the first structural proof for the existence of monomeric $\mathrm{Zr}^{\mathrm{IV}}$-Keggin and $\mathrm{Hf}^{\mathrm{IV}}$-Wells-Dawson POMs under neutral $\mathrm{pH}$ conditions, as these species have previously only been detected through spectro-

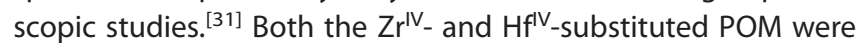

106 found in the same void in the HEWL crystal, elucidating three distinct binding sites. Furthermore, both crystal structures displayed a similar level of hydrogen-bonding and water-mediated interactions between the metal-substituted POM and the protein. Interestingly, a direct interaction between the $\mathrm{Zr}^{\mathrm{IV}}$ or $\mathrm{Hf}^{\mathrm{IV}}$

111 metal and the peptide bond could not be observed in either structure. However, in a more recent work, a dimeric $\mathrm{Zr}^{\mathrm{IV}}$-substituted Keggin type POM $\left[\left\{\alpha-\mathrm{PW}_{11} \mathrm{O}_{39} \mathrm{Zr}-(\mu-\mathrm{OH})\left(\mathrm{H}_{2} \mathrm{O}\right)\right\}_{2}\right]^{8-}$ was cocrystallized with $\mathrm{HEWL}$, yielding a structural model that showed direct binding of the $\mathrm{Zr}^{\mathrm{IV}}$ ion to the carbonylic oxygen of the

116 side chain of Asn65. ${ }^{[32]}$ This crystal structure was the first example that indicated that the Lewis acid metal could play a role in the binding of POMs to proteins. In this work we aim to further investigate the role of the imbedded metal ion on the $\mathrm{POM} /$ protein interactions by studying the binding between four

121 different metal-substituted Wells-Dawson POMs and HEWL. Successful co-crystallization has yielded four structural models of noncovalent complexes formed between HEWL and $\mathrm{Zr}^{\mathrm{IV}}$, $\mathrm{Co}^{\prime \prime}$-, Ni"- and Cu"-Wells-Dawson POMs, thus providing an insight into the effect of the imbedded metal on interactions with 126 a protein.

\section{Results and Discussion}

HEWL was mixed with four Wells-Dawson type POMs: a dimeric $\left[\mathrm{Zr}^{\mathrm{rV}}\left(\alpha_{2}-\mathrm{P}_{2} \mathrm{~W}_{17} \mathrm{O}_{61}\right)_{2}\right]^{16-}$ and three monomeric POMs [Co" $\left(\alpha_{2}-\right.$ $\left.\left.\mathrm{P}_{2} \mathrm{~W}_{17} \mathrm{O}_{61}\right)\right]^{10-}(\mathbf{2}), \quad\left[\mathrm{Ni}^{\prime \prime}\left(\alpha_{2}-\mathrm{P}_{2} \mathrm{~W}_{17} \mathrm{O}_{61}\right)\right]^{10-}$ (3) and $\left[\mathrm{Cu}^{\prime \prime}\left(\alpha_{2}-\right.\right.$

$\left.\left.131 \mathrm{P}_{2} \mathrm{~W}_{17} \mathrm{O}_{61}\right)\right]^{10-}(\mathbf{4})$, resulting in four structural models. Similarly to previously observed, ${ }^{[29,30]}$ during the crystallization process the dimeric 1:2 Zr' ${ }^{\prime V}$-Wells-Dawson POM dissociated into mono- meric 1:1 $\mathrm{Zr}^{\mathrm{IV}}$-Wells-Dawson anion $\left[\mathrm{Zr}^{\mathrm{IV}}\left(\alpha_{2}-\mathrm{P}_{2} \mathrm{~W}_{17} \mathrm{O}_{61}\right)\right]^{8-}$ (1) (Scheme 1), which crystalized in a noncovalent complex with HEWL.

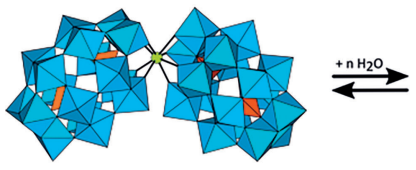

$1: 2$

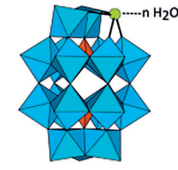

$1: 1$

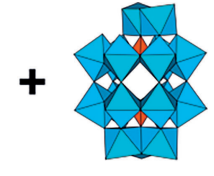

$0: 1$
Scheme 1. Dissociation of the sandwich type 1:2 MSP into the monomeric 1:1 and lacunary 0:1 form. The blue polyhedra depict the tungstate moieties; phosphate is depicted as orange tetrahedral and the substituted metal is depicted as a green sphere.

Data collection and refinement statistics for HEWL-1, HEWL2, HEWL-3 and HEWL-4 can be found in Table 1. The crystals were obtained under relatively similar conditions of $\mathrm{pH}$ $(4.0-5.5)$. The slightly acidic medium was necessary to provide enough positive charge on the protein for the electrostatic in- 141 teraction with the negatively charged POM. All co-crystals have the same common packing of HEWL (space group $P 4_{3} 2_{1} 2$ ) and the monomeric POMs are all bound in the same void of the crystal. Notably, the POM is located on a twofold rotation axis and therefore both symmetry equivalents contribute to the to- 146 tal occupancy in a 50:50 ratio. Figure 1 visualizes the electron density fit of the MSPs as observed in the co-crystal structures.

During refinement the total occupancies of the MSPs in the structural models converged to $64 \%$ (HEWL-1), $46 \%$ (HEWL2), $100 \%$ (HEWL-3) and $32 \%$ (HEWL-4). Unfortunately, it is not 151 possible to correlate the observed occupancy to a potential trend in binding affinity, since the crystals were not grown in strictly identical conditions.

By analyzing the refined co-crystal structures (Table 2), a clear side-by-side comparison of POM-HEWL interaction sites 156 could be made. Similarly to the previously reported structures of HEWL with $\mathrm{Zr}^{\prime \mathrm{V}}$-Keggin and $\mathrm{H}^{\mathrm{IV}}$-Wells-Dawson POMs, three distinct interaction sites were observed in all crystals (Figure 2). ${ }^{[29,30]}$ Each interaction site consists of two slightly different POM binding modes with HEWL, due to its aforementioned 161 special position in the crystal (Figure 1). In all cases, the substituted metal $\left(\mathrm{Zr}^{\mathrm{IV}}, \mathrm{Co}^{\prime \prime}, \mathrm{Ni}\right.$ " or $\left.\mathrm{Cu}^{\prime \prime}\right)$ in the POM structure is facing away from the protein surface. However, by comparing the positions of the Lewis acid metals two different orientations of the substituted metal were found in the electron density: one 166 orientation is found for $\mathrm{Co}^{\prime \prime} / \mathrm{Ni}^{\prime \prime}$ and another one for $\mathrm{Zr}^{\prime \mathrm{V}} / \mathrm{Cu}^{\prime \prime}$ (Figure 3). The position of $\mathrm{Zr}^{\mathrm{IV}}$ and $\mathrm{Cu}^{\prime \prime}$ are at the same side of the POM framework, similar to the position of $\mathrm{Hf}^{\mathrm{IV}}$ in a previously reported structure. ${ }^{[30]}$ However, $\mathrm{Co}^{\mathrm{II}}$ and $\mathrm{Ni}$ " were found on the opposite side of the POM framework with respect to 171 the position of $\mathrm{Zr}^{\mathrm{IV}}$ and $\mathrm{Cu}^{\prime \prime}$. These findings suggest that the substituted metal has no preferred orientation, but that it tends to be positioned away from the protein surface.

In order to further investigate the exact nature of these interactions, we visually inspected the polar interactions between 176 POMs and HEWL at the three binding sites. For this, only direct and interactions mediated by a single water molecule were taken into account. In Table 2, the observed interaction sites with specific HEWL residues are listed for the refined crystal 
Table 1. Data collection and refinement statistics for the co-crystals of HEWL-1, HEWL-2, HEWL-3 and HEWL-4.

\begin{tabular}{|c|c|c|c|c|}
\hline \multirow{2}{*}{$\frac{\text { Parameter }}{\text { Co-crystal }}$} & \multicolumn{4}{|l|}{ Value } \\
\hline & HEWL-1 & HEWL-2 & HEWL-3 & HEWL-4 \\
\hline MSP & 1:1 Zr' ${ }^{\prime V}$-Wells-Dawson & 1:1 Co"-Wells-Dawson & 1:1 Ni"-Wells-Dawson & 1:1 Cu"-Wells-Dawson \\
\hline PDB deposition code & $6 \mathrm{HYB}$ & $6 \mathrm{HY} 4$ & $6 \mathrm{HY} 6$ & $6 \mathrm{HY} 8$ \\
\hline Space group & $P 4{ }_{3} 2,2$ & $P 4_{3} 2,2$ & $P 4_{3} 2_{1} 2$ & $P 4_{3} 2_{2} 2$ \\
\hline \multirow[t]{3}{*}{ Unit cell dimensions [Å] } & $a=78.61$ & $a=78.73$ & $a=78.94$ & $a=78.84$ \\
\hline & $b=78.61$ & $b=78.73$ & $b=78.94$ & $b=78.84$ \\
\hline & $c=37.11$ & $c=37.18$ & $c=37.27$ & $c=37.19$ \\
\hline Resolution range $[\AA]]$ & $35.16-1.96(2.08-1.96)^{[a]}$ & $39.37-1.83(1.93-1.83)^{[a]}$ & $39.47-1.87(1.91-1.87)^{[a]}$ & $39.42-1.22(1.24-1.42)^{[a]}$ \\
\hline$R_{\text {merge }}[\%]$ & $10.6(80.6)^{[a]}$ & $13.0(76.1)^{[\mathrm{a}]}$ & $14.4(78.7)^{[\mathrm{a}]}$ & $8.2(75.0)^{[a]}$ \\
\hline$<1 / \sigma>$ & $15.89(2.85)^{[\mathrm{a}]}$ & $14.4(3.1)^{[\mathrm{a}]}$ & $20.5(6.1)^{[\mathrm{a}]}$ & $28.0(4.5)^{[\mathrm{a}]}$ \\
\hline No. of unique reflections & $8603(1239)^{[a]}$ & $10817(658)^{[a]}$ & $10230(9529)^{[a]}$ & $35507(1740)^{[a]}$ \\
\hline Multiplicity & $13.8(13.6)^{[\mathrm{a}]}$ & $13.4(12.8)^{[a]}$ & $14.1(14.9)^{[\mathrm{a}]}$ & $23.8(22.9)^{[\mathrm{a}]}$ \\
\hline Completeness [\%] & $98.6(91.2)^{[a]}$ & $100.0(100.0)^{[\mathrm{a}]}$ & $100.0(100.0)^{[\mathrm{a}]}$ & $100.0(99.9)^{[a]}$ \\
\hline $\begin{array}{l}R_{\text {work }} / R_{\text {free }}{ }^{[\mathrm{b}]}[\%] \\
\text { RMSD from ideal }\end{array}$ & $17.10 / 20.45$ & $17.68 / 21.45$ & $16.23 / 19.19$ & $13.84 / 15.49$ \\
\hline Bond lengths $[\AA ̊]$ & 0.006 & 0.015 & 0.012 & 0.006 \\
\hline Bond angles $\left[^{\circ}\right]$ & 0.771 & 1.547 & 1.188 & 0.963 \\
\hline \multicolumn{5}{|l|}{ Average isotropic B-factors $\left[\AA^{2}\right]$} \\
\hline Main chain & 33.32 & 27.17 & 22.20 & 13.93 \\
\hline Side chain & 41.91 & 34.75 & 28.73 & 18.95 \\
\hline MSP & 38.98 & 19.90 & 21.39 & 13.51 \\
\hline Water molecules & 39.85 & 34.02 & 31.25 & 25.36 \\
\hline \multicolumn{5}{|l|}{ Ramachandran plot ${ }^{[c]}[\%]$} \\
\hline Residues in favoured regions & 99.2 & 96.0 & 99.2 & 98.4 \\
\hline Outliers & 0.00 & 0.00 & 0.00 & 0.00 \\
\hline
\end{tabular}

[a] Values in parentheses are for the highest resolution shell. [b] Rfree is calculated using a random $5 \%$ of data excluded from the refinement. [c] Ramachandran analysis was carried out using molprobity. ${ }^{[33]}$
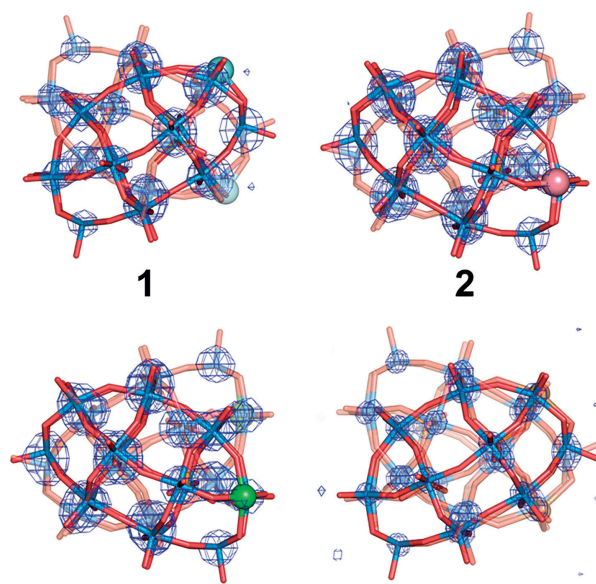

3

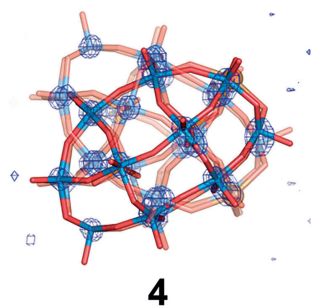

Figure 1. Fit of the MSPs in the $2 F_{o}-F_{c}$ electron density map (shown as blue mesh), contoured at 5.0 r.m.s.d. The polyoxometalate framework is shown as sticks, where tungsten is colored blue; oxygen is colored red and phosphorus is colored orange. Each transition metal is shown as a sphere and colorcoded: light blue for $\mathrm{Zr}^{\mathrm{IV}}$; pink for $\mathrm{Co}^{\mathrm{II}}$; green for $\mathrm{Ni}^{\mathrm{Il}}$ and dark-orange for $\mathrm{Cu}^{\mathrm{II}}$. The symmetry equivalent of the MSP is shown in slightly faded colors. structures. Clearly, the interaction sites for the Wells-Dawson 181 archetype MSPs are identical in the space group $\mathrm{P}_{3} 2_{2} 2$. Table 2 shows that several residues at each interaction site seem to be essential for the interaction, as these recur in all four of the crystal structures. The residues Tyr20, Arg21 and Lys96 are representative for the first interaction site ( $\alpha$-helix, loop); Arg45 186 and Asn46 for the second ( $\beta$-sheet, loop), whereas Arg128 represents the last interaction site (C-terminal end). These interaction sites are identical to previously reported complexes

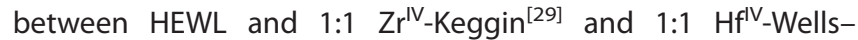
Dawson $^{[30]}$ POMs. The fact that most of the interacting HEWL 191 residues are found in flexible loop regions suggests that this is a characteristic feature for the binding mode of POMs in general.

Moreover, POM binding might actually rigidify these unstructured HEWL regions and thereby induce a higher degree of structural stability. As mentioned above, various POMs are used 196 for crystallization purposes because they preferably interact with flexible, unstructured protein regions and rigidify them. This was concluded from an analysis on 30 PDB structures where $65 \%$ of the POM interacting protein structural elements were of flexible, loop or loop-like nature. ${ }^{[21]}$

Table 2. Comparison of direct and water-mediated interactions involved in each structural model for the three observed binding sites. Direct interactions are shown in bold, the others are water-mediated.

\begin{tabular}{|c|c|c|c|c|}
\hline Crystal structure & Lewis acid metal & Site 1 & Site 2 & Site 3 \\
\hline HEWL-1 & $\mathrm{Zr}^{\mathrm{IV}}$ & G16, Y20, R21, N93, K96 & R45, N46 ${ }^{[a]}$ & $\mathrm{R} 128^{[\mathrm{a}]}$ \\
\hline HEWL-2 & Co" & H15, G16, ${ }^{[\mathrm{a}]}$ Y20, R21, N93, ${ }^{[\mathrm{a}]}$ K96 & $\mathrm{R} 45, \mathbf{N} 46^{[\mathrm{a}]}$ & $\mathrm{R} 128$ \\
\hline HEWL-3 & $\mathrm{Ni}^{\prime \prime}$ & $\mathbf{G} 16,{ }^{[\mathrm{a}]} \mathbf{Y} 2 \mathbf{2}^{[\mathrm{a}]} \mathrm{R} 21, \mathbf{N} 9 \mathbf{3}^{[\mathrm{a}]} \mathbf{K} \mathbf{9 6}, \mathrm{S} 100$ & $\mathrm{~N} 44, \mathbf{R} 45^{[\mathrm{a}]} \mathbf{N} 46^{[\mathrm{a}]} \mathbf{T} 4 \mathbf{7}^{[\mathrm{a}]}$ & R128 \\
\hline HEWL-4 & $\mathrm{Cu}^{\prime \prime}$ & $\mathrm{H} 15, \mathbf{G 1 6}{ }^{[\mathrm{a}]} \mathrm{N} 19, \mathbf{Y} 2 \mathbf{r}^{[\mathrm{a}]} \mathrm{R} 21, \mathbf{N} 9 \mathbf{3}^{[\mathrm{al}]} \mathbf{K} \mathbf{9 6}, \mathbf{K} \mathbf{9 7},{ }^{\text {[a] }} \mathrm{S} 100$ & N44, R45, N46, ${ }^{[\mathrm{a}]} \mathbf{T 4 7}^{\text {[a] }}$ & $\mathrm{R} 128$ \\
\hline
\end{tabular}

[a] Direct interaction being partially water-mediated. 

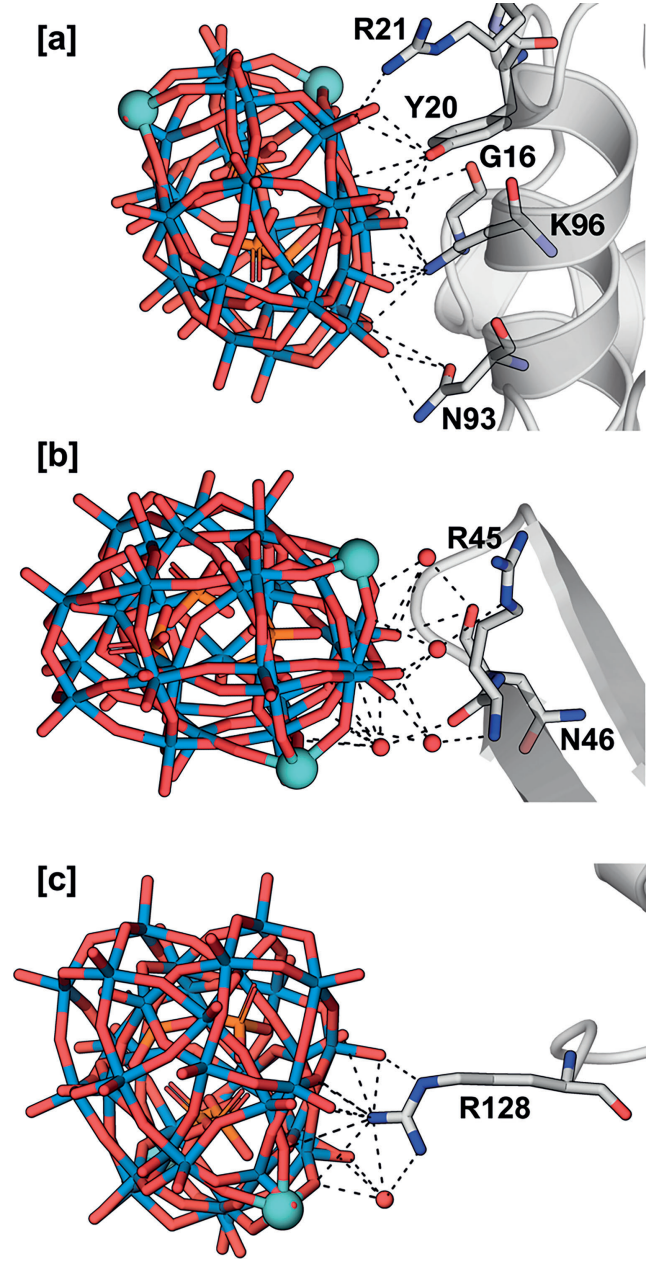

Figure 2. Interactions of the POM with HEWL at the three binding sites: site 1 [a], site $2[\mathrm{~b}]$ and site $3[\mathrm{c}]$. The structure of HEWL-1 is used to illustrate the interactions occurring for all POMs in this work. The polyoxometalate framework is shown as sticks, where tungsten is colored blue; oxygen is colored red and phosphorus is colored orange. The $\mathrm{Zr}^{\mathrm{rV}}$ atom is shown as a light blue sphere and the polar interactions are shown as black dashes. Both symmetry equivalent POMs are shown simultaneously.

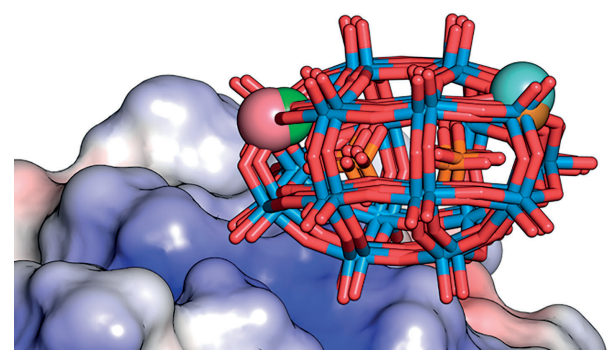

Figure 3. Orientation of the substituted metal of the MSPs in the structural model at interaction site 1. The polyoxometalate framework is shown as sticks, where tungsten is colored blue; oxygen is colored red and phosphorus is colored orange. Each transition metal is shown as a sphere and colorcoded: light blue for Zr'v; pink for Co"l; green for Nill and dark-orange for $\mathrm{Cu}^{\prime \prime}$. The protein surface is shown as an electrostatic surface, where blue is positive, white is neutral and red is negative.

Representative polar interactions are visualized in Figure 2 and Figure S1. From the Figure it is clear that interaction only occurs between the POM framework and HEWL residues, whereas the substituted metal is not involved in the interaction process. The interactions are mainly established by nonspecific 206 direct or water-mediated interactions between the terminal oxygen atoms of the POM framework and HEWL amino acids. Therefore, the mode of binding is independent of the substituted metal and it is the POM framework that plays the most crucial part for the interactions with the protein. The ordered 211 waters in proximity to the MSP were difficult to model unambiguously and the amount of observed ordered waters is strongly dependent on the resolution of the crystal structure.

In Figure 4A, the four HEWL-POM co-crystal structures were aligned with a native HEWL structure (PDB code: 1LYZ, used 216 as phasing model). Additionally, the reported crystallographic structure of HEWL-Hfl'-Wells-Dawson (PDB code: $5 \mathrm{FHW}$ ) is included in the alignment to obtain a global view of differences and similarities between various HEWL-POM crystal structures crystallized in space group $P 4_{3} 2_{1} 2$. As seen in Figure $4 A$, the 221 three interaction sites on HEWL are identical and clearly independent of the nature of substituted metal. Comparison with the native HEWL structure of the phasing model (r.m.s.d. = $0.41 \AA$ ) indicated that the overall fold of HEWL is largely unaffected by the POM (blue cartoon). Some deviation is only ob- 226

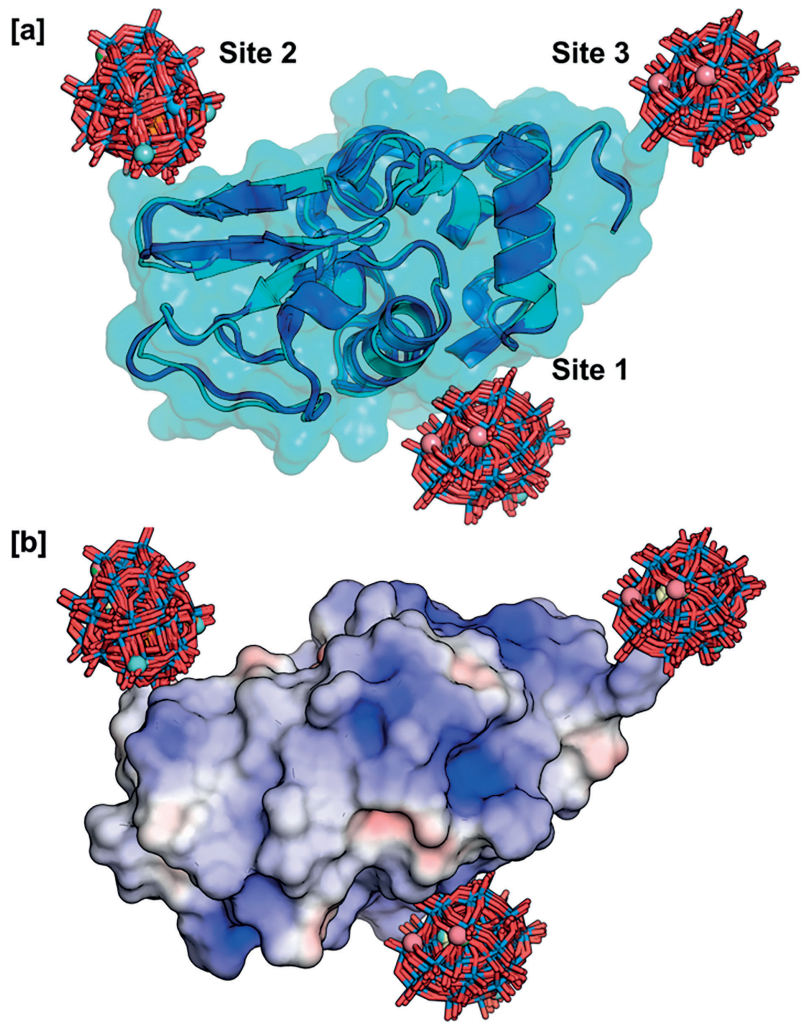

Figure 4. Superposition of HEWL-1, 2,3,4, native HEWL (cyan cartoon and surface, PDB code: $1 \mathrm{LYZ}$ ) and HEWL-Hf ${ }^{1 \mathrm{~V}}$-Wells-Dawson (dark blue, PDB code: $5 \mathrm{FHW}$ ), indicating the three binding sites and the highly similar fold [a]. The same image is shown with the electrostatic surface potential of HEWL to show the charges at the binding sites [b]. The polyoxometalate framework is shown as sticks, where tungsten is colored blue; oxygen is colored red and phosphorus is colored orange. Each transition metal is shown as a sphere and color-coded: light blue for $\mathrm{Zr}^{\mathrm{r}}$; pink for $\mathrm{Co}^{\mathrm{ll}}$; green for $\mathrm{Ni}^{\mathrm{ll}}$ and darkorange for $\mathrm{Cu}^{\prime \prime}$. The protein surface in [b] is shown as an electrostatic surface, where blue is positive, white is neutral and red is negative. 
served in loops and interestingly, this deviation is almost identical for all the aligned HEWL-POM structures. Figure 4B presents the electrostatic potential maps of HEWL, indicating that all POM binding sites are located at the positively charged surface

231 regions of HEWL. These observations strongly support previous findings that have shown that $\mathrm{POM} /$ protein interactions are mainly electrostatic in nature. ${ }^{[7,12,15,29,30]}$

\section{Conclusions}

In this study, the interaction between four different metal-sub236 stituted POMs and HEWL protein were compared on a molecular level. The single crystal structures of the noncovalent complexes formed between POMs and HEWL suggest that the interaction is largely independent on the nature of the substituted metal within the same POM archetype. The electrostatic attrac-

241 tion between POM and HEWL surface regions is the main driving force for the formation of noncovalent complexes. Further stabilization is provided by direct and water-mediated hydrogen bonding between terminal oxygen atoms in the POM framework and flexible HEWL residues. The orientation of the

246 substituted metal in the POM/protein complex is seemingly random, but in all cases the metal is facing away from the interaction site and it does not interact with the protein surface.

\section{Experimental Section}

Materials

251 The $\quad 1: 2 \quad Z^{I V}$-Wells-Dawson $\quad \mathrm{K}_{16}\left[\mathrm{Zr}\left(\alpha_{2}-\mathrm{P}_{2} \mathrm{~W}_{17} \mathrm{O}_{61}\right)_{2}\right] \cdot 19 \mathrm{H}_{2} \mathrm{O},{ }^{[34]}$ $\mathrm{K}_{8}\left[\mathrm{CO}^{\prime \prime}\left(\alpha_{2}-\mathrm{P}_{2} \mathrm{~W}_{17} \mathrm{O}_{61}\right)\right] \cdot 16 \mathrm{H}_{2} \mathrm{O}^{[35]} \mathrm{K}_{8}\left[\mathrm{Ni}^{\prime \prime}\left(\alpha_{2}-\mathrm{P}_{2} \mathrm{~W}_{17} \mathrm{O}_{61}\right)\right] \cdot 16 \mathrm{H}_{2} \mathrm{O}^{[35]}$ and $\mathrm{K}_{8}\left[\mathrm{Cu}^{\prime \prime}\left(\alpha_{2}-\mathrm{P}_{2} \mathrm{~W}_{17} \mathrm{O}_{61}\right)\right] \cdot 17 \mathrm{H}_{2} \mathrm{O}^{[35]}$ were synthesized as described in literature. All chemicals required for the synthesis of the MSPs, the preparation of buffers and solutions were purchased from commer-

256 cial sources and are used without further purification. Hen egg white lysozyme (HEWL) was acquired from Sigma Aldrich in the highest purification grade and was used without any further purification for co-crystallization.

\section{Co-crystallization}

261 Co-crystals of HEWL-1 were grown with $1 \mathrm{~m}$ lithium chloride, $30 \%$ (w/v) PEG 6000 and $0.1 \mathrm{M}$ citric acid ( $\mathrm{pH} 4.0$ ) as precipitant. Sitting drops containing $1 \mu \mathrm{L}$ of HEWL $\left(25 \mathrm{mg} \mathrm{mL}^{-1}=1.75 \mathrm{mM}\right.$, dissolved in $10 \mathrm{mM}$ phosphate buffer, $\mathrm{pH} 7.4), 1 \mu \mathrm{L}$ of $\mathrm{K}_{16}\left[\mathrm{Zr}\left(\alpha_{2}-\mathrm{P}_{2} \mathrm{~W}_{17} \mathrm{O}_{61}\right)_{2}\right]$. $19 \mathrm{H}_{2} \mathrm{O}(0.8 \mathrm{~mm}$, dissolved in distilled water) and $1 \mu \mathrm{L}$ precipitant,

266 were equilibrated against a reservoir of $70 \mu \mathrm{L}$ precipitant.

Co-crystals of HEWL-2 were grown with $0.5 \mathrm{~m}$ lithium chloride, $30 \%$ (w/v) PEG 6000 and $0.1 \mathrm{M}$ citric acid ( $\mathrm{pH} 4.0$ ) as precipitant. Sitting drops containing $1 \mu \mathrm{L}$ of HEWL (20 mg mL $\mathrm{mb}^{-1}=1.40 \mathrm{~mm}$, dissolved in $10 \mathrm{~mm}$ phosphate buffer, $\mathrm{pH} 7.4), 1 \mu \mathrm{L}$ of $\mathrm{K}_{8}\left[\mathrm{Co}^{\prime \prime}\left(\alpha_{2}-\mathrm{P}_{2} \mathrm{~W}_{17} \mathrm{O}_{61}\right)\right]$.

$27116 \mathrm{H}_{2} \mathrm{O}(1 \mathrm{~mm}$, dissolved in distilled water) and $1 \mu \mathrm{L}$ precipitant, were equilibrated against a reservoir of $70 \mu \mathrm{L}$ precipitant.

Co-crystals of HEWL-3 were grown with $0.75 \mathrm{~m}$ lithium chloride, $30 \%(\mathrm{w} / \mathrm{v})$ PEG 6000 and $0.1 \mathrm{M}$ citric acid $(\mathrm{pH} 4.0)$ as precipitant. Sitting drops containing $1 \mu \mathrm{L}$ of HEWL $\left(20 \mathrm{mg} \mathrm{mL}^{-1}=1.40 \mathrm{~mm}\right.$,

276 dissolved in $10 \mathrm{~mm}$ phosphate buffer, $\mathrm{pH} 7.4), 1 \mu \mathrm{L}$ of $\mathrm{K}_{8}\left[\mathrm{Ni}^{\prime \prime}\left(\alpha_{2}-\right.\right.$ $\left.\left.\mathrm{P}_{2} \mathrm{~W}_{17} \mathrm{O}_{61}\right)\right] \cdot 16 \mathrm{H}_{2} \mathrm{O}(1 \mathrm{~mm}$, dissolved in distilled water) and $1 \mu \mathrm{L}$ precipitant, were equilibrated against a reservoir of $70 \mu \mathrm{L}$ precipitant.

Co-crystals of HEWL-4 were grown with $2.6 \mathrm{M}$ sodium chloride and $0.1 \mathrm{M}$ Bis-Tris ( $\mathrm{pH}$ 5.5) as precipitant. Sitting drops containing $1 \mu \mathrm{L}$ of HEWL (25 mg mL $\mathrm{mL}^{-1}=1.75 \mathrm{~mm}$, dissolved in $10 \mathrm{~mm}$ phosphate 281 buffer, $\mathrm{pH} 7.4), 1 \mu \mathrm{L}$ of $\mathrm{K}_{8}\left[\mathrm{Cu}^{\prime \prime}\left(\alpha_{2}-\mathrm{P}_{2} \mathrm{~W}_{17} \mathrm{O}_{61}\right)\right] \cdot 17 \mathrm{H}_{2} \mathrm{O}(0.8 \mathrm{~mm}$, dissolved in distilled water) and $1 \mu \mathrm{L}$ precipitant, were equilibrated against a reservoir of $70 \mu \mathrm{L}$ precipitant.

Before the X-ray diffraction experiment, the crystals were flash frozen in liquid nitrogen, using $20 \%$ (m/v) PEG 400 as cryoprotectant. 286

\section{Structure Determination}

X-ray data were collected on a Pilatus $6 M$ detector at the PROXIMA 1 beamline of Soleil (Saint-Aubin, France), using a wavelength of $0.9786 \AA$ and a cold nitrogen stream of $100 \mathrm{~K}$. The data was analyzed using XDS v. January 16, 2018, ${ }^{[36]}$ and scaled and merged 291 using Aimless v. 0.6.2. ${ }^{[37]}$ As the POM induced an anomalous signal, Friedel pairs were not merged. The phase problem was solved using molecular replacement, using Phaser v. 2.8.0 $0^{[38]}$ with HEWL (PDB ID: $1 \mathrm{LYZ})^{[39]}$ as phasing model. Structure refinement was performed using Phenix.refine v.1.12 $2^{[40]}$ and COOT v.0.8.2. ${ }^{[41]}$ After a first round 296 of refinement, the tungsten and transition metal atoms of the MSPs appeared very clear in both the $2 \mathrm{mFo}-\mathrm{DFc}$ and the mFo-DFc difference map. The transition metals have significantly less electron density and could therefore unambiguously be fit into the electron density map (Figure 1). The crystallographic restraints file for $\mathbf{1} 301$ was manually generated based on the geometry of $\mathrm{K}_{16}\left[\mathrm{Zr}\left(\alpha_{2^{-}}\right.\right.$ $\left.\left.\mathrm{P}_{2} \mathrm{~W}_{17} \mathrm{O}_{61}\right)_{2}\right] \cdot 19 \mathrm{H}_{2} \mathrm{O}^{\left[{ }^{[3]}\right.}$ The crystallographic restraints files for $\mathbf{2}$ and 3 were manually generated based on the crystal structure of $\mathrm{K}_{8}\left[\mathrm{Co}^{\prime \prime}\left(\alpha_{2}-\mathrm{P}_{2} \mathrm{~W}_{17} \mathrm{O}_{61}\right)\right] \cdot 16 \mathrm{H}_{2} \mathrm{O} .^{[42]}$ The Ni"-Wells-Dawson is nearly isostructural to the Co"-Wells-Dawson, which permitted us to create 306 similar restraints from one crystal structure. The crystallographic restraints file for $\mathbf{4}$ was manually generated based on the crystal structure of $\mathrm{K}_{8}\left[\mathrm{Cu}^{\prime \prime}\left(\alpha_{2}-\mathrm{P}_{2} \mathrm{~W}_{17} \mathrm{O}_{61}\right)\right] \cdot 17 \mathrm{H}_{2} \mathrm{O}^{[43]}$ During further refinement cycles, chloride ions and water molecules were added to the model when they had reasonable electron density levels in the 2mFo-DFc 311 and mFo-DFc maps, B-factors below $80 \AA^{2}$ and within hydrogenbonding distances to possible donors or acceptors. Data collection and refinement statistics for HEWL-1, HEWL-2, HEWL-3 and HEWL-4 can be found in Table 1. The final models were deposited in the Protein Data Bank under accession codes 6HYB (HEWL-1), 6HY4 316 (HEWL-2), 6HY6 (HEWL-3) and 6HY8 (HEWL-4). Figures were prepared using Pymol. ${ }^{[4]}$ Electrostatic surfaces were calculated and visualized using the PDB2PQR webtool and the Pymol APBS plugin. ${ }^{[45]}$

CCDC \#\#\#\# (for HEWL-1), \#\#\#\#\# (for HEWL-2), \#\#\#\# (for HEWL-3), 321 and \#\#\#\# (for HEWL-4) contain the supplementary crystallographic data for this paper. These data can be obtained free of charge from The Cambridge Crystallographic Data Centre $1(<=$ Author please provide the CCDC number for each compound.))

\section{Acknowledgments}

We thank the staff of the PROXIMA 1 beamline at Soleil (SaintAubin, France) for assistance with data collection. L. V. thanks Research Foundation-Flanders (FWO Flanders) for a doctoral fellowship. T. P. V. and L. V. M. thank FWO (G0E4717N) for funding.

Keywords: Polyoxometalates - Transition metals - Protein 331 structures - Electrostatic interactions

[1] S.-S. Wang, G.-Y. Yang, Chem. Rev. 2015, 115, 4893-4962.

[2] M.-P. Santoni, G. S. Hanan, B. Hasenknopf, Coord. Chem. Rev. 2014, 281, 64-85.

[3] H. N. Miras, J. Yan, D.-L. Long, L. Cronin, Chem. Soc. Rev. 2012, 41, 7403. 336 
[4] J. M. Clemente-Juan, E. Coronado, A. Gaita-Ariño, Chem. Soc. Rev. 2012, 41, 7464.

[5] A. Bijelic, M. Aureliano, A. Rompel, Chem. Commun. 2018, 54, 1153-1169.

[6] B. Hasenknopf, Front. Biosci. 2005, 10, 275.

341 [7] V. Goovaerts, K. Stroobants, G. Absillis, T. N. Parac-Vogt, Inorganics 2015, 3, 230-245.

[8] A. Solé-Daura, V. Goovaerts, K. Stroobants, G. Absillis, P. Jiménez-Lozano, J. M. Poblet, J. D. Hirst, T. N. Parac-Vogt, J. J. Carbó, Chem. Eur. J. 2016, 22, 15280-15289.

346 [9] D. Kobayashi, H. Nakahara, O. Shibata, K. Unoura, H. Nabika, J. Phys. Chem. C 2017, 121, 12895-12902.

[10] C. Molitor, A. Bijelic, A. Rompel, Chem. Commun. 2016, 52, 12286-12289.

[11] G. Absillis, T. N. Parac-Vogt, Inorg. Chem. 2012, 51, 9902-9910.

[12] K. Stroobants, E. Moelants, H. G. T. Ly, P. Proost, K. Bartik, T. N. Parac-Vogt, Chem. Eur. J. 2013, 19, 2848-2858.

[13] H. G. T. Ly, G. Absillis, R. Janssens, P. Proost, T. N. Parac-Vogt, Angew. Chem. Int. Ed. 2015, 54, 7391-7394; Angew. Chem. 2015, 127, 7499.

[14] S. Vanhaecht, G. Absillis, T. N. Parac-Vogt, Dalton Trans. 2013, 42, 15437.

[15] V. Goovaerts, K. Stroobants, G. Absillis, T. N. Parac-Vvogt, J. Inorg. Bio356 chem. 2015, 150, 72-80.

[16] P.-F. Gao, S. Zhang, H.-W. Li, T. Zhang, Y. Wu, L. Wu, Langmuir 2015, 31, 10888-10896.

[17] L. Zheng, Y. Ma, G. Zhang, J. Yao, B. Keita, L. Nadjo, Phys. Chem. Chem. Phys. 2010, 12, 1299-1304.

361 [18] G. Zhang, B. Keita, C. T. Craescu, S. Miron, P. de Oliveira, L. Nadjo, Biomacromolecules 2008, 9, 812-817.

[19] G. Hungerford, F. Hussain, G. R. Patzke, M. Green, Phys. Chem. Chem. Phys. 2010, 12, 7266-7275.

[20] H. G. T. Ly, T. N. Parac-Vogt, ChemPhysChem 2017, 18, 2451-2458.

366 [21] A. Bijelic, A. Rompel, Coord. Chem. Rev. 2015, 299, 22-38.

[22] A. Blazevic, A. Rompel, Coord. Chem. Rev. 2016, 307, 42-64.

[23] A. Tocilj, F. Schlünzen, D. Janell, M. Glühmann, H. A. S. Hansen, J. Harms, A. Bashan, H. Bartels, I. Agmon, F. Franceschi, et al., Proc. Natl. Acad. Sci. USA 1999, 96, 14252-14257.

371 [24] F. Schluenzen, A. Tocilj, R. Zarivach, J. Harms, M. Gluehmann, D. Janell, A. Bashan, H. Bartels, I. Agmon, F. Franceschi, et al., Cell 2000, 102, 615623.

[25] H. G. T. Ly, G. Absillis, T. N. Parac-Vogt, New J. Chem. 2016, 40, 976-984.

[26] T. T. Mihaylov, H. G. T. Ly, K. Pierloot, T. N. Parac-Vogt, Inorg. Chem. 2016, 376 $55,9316-9328$.
[27] H. G. T. Ly, G. Absillis, T. N. Parac-Vogt, Dalton Trans. 2013, 42, 10929.

[28] H. G. T. Ly, G. Absillis, S. R. Bajpe, J. A. Martens, T. N. Parac-Vogt, Eur. J. Inorg. Chem. 2013, 4601-4611.

[29] A. Sap, E. De Zitter, L. Van Meervelt, T. N. Parac-Vogt, Chem. Eur. J. 2015, 21, 11692-11695.

[30] L. Vandebroek, E. De Zitter, H. G. T. Ly, D. Conić, T. Mihaylov, A. Sap, L. Van Meervelt, K. Pierloot, P. Proost, T. N. Parac-Vogt, Chem. Eur. J. 2018, https://doi.org/https://doi.org/10.1002/chem.201802052.

[31] T. K. N. Luong, P. Shestakova, T. T. Mihaylov, G. Absillis, K. Pierloot, T. N. Parac-Vogt, Chem. Eur. J. 2015, 21, 4428-4439.

[32] L. Vandebroek, L. Van Meervelt, T. N. Parac-Vogt, Acta Crystallogr., Sect. C 2018, 74, https://doi.org/10.1107/S2053229618010690.

[33] V. B. Chen, W. B. Arendall, J. J. Headd, D. A. Keedy, R. M. Immormino, G. J. Kapral, L. W. Murray, J. S. Richardson, D. C. Richardson, Acta Crystallogr., Sect. D Biol. Crystallogr. 2010, 66, 12-21.

[34] C. N. Kato, A. Shinohara, K. Hayashi, K. Nomiya, Inorg. Chem. 2006, 45, 8108-8119.

[35] D. K. Lyon, W. K. Miller, T. Novet, P. J. Domaille, E. Evitt, D. C. Johnson, R. G. Finke, J. Am. Chem. Soc. 1991, 113, 7209-7221.

[36] W. Kabsch, Acta Crystallogr., Sect. D Biol. Crystallogr. 2010, 66, 125-132. 396

[37] P. R. Evans, G. N. Murshudov, Acta Crystallogr., Sect. D Biol. Crystallogr. 2013, 69, 1204-1214.

[38] A. J. McCoy, R. W. Grosse-Kunstleve, P. D. Adams, M. D. Winn, L. C. Storoni, R. J. Read, J. Appl. Crystallogr. 2007, 40, 658-674.

[39] R. Diamond, J. Mol. Biol. 1974, 82, 371-391.

[40] P. V. Afonine, R. W. Grosse-Kunstleve, N. Echols, J. J. Headd, N. W. Moriarty, M. Mustyakimov, T. C. Terwilliger, A. Urzhumtsev, P. H. Zwart, P. D. Adams, Acta Crystallogr., Sect. D 2012, 68, 352-367.

[41] P. Emsley, K. Cowtan, Acta Crystallogr., Sect. D Biol. Crystallogr. 2004, 60, 2126-2132.

[42] B. Li, Z. Dan, G.-Y. Yang, J. Cluster Sci. 2009, 20, 629-639.

[43] H.-S. Liu, J. Peng, L.-X. Wang, Z. Anorg. Allg. Chem. 2009, 635, 2688-2691.

[44] L. L. C. Schrödinger, The $\{$ PyMOL $\{$ M\}olecular $\{G\}$ raphics $\{S\} y s t e m$, Version 1.3r1, 2010.

[45] W. L. DeLano, Schrödinger LLC wwwpymolorg 2002, Version 1, http:// 411 www.pymol.org-http://www.pymol.org.

Received: September 15, 2018 
Protein Binding to POMs

416 L. Vandebroek, Y. Mampaey,

S. Antonyuk, L. Van Meervelt,

T. N. Parac-Vogt* $1-7$

421

Noncovalent Complexes Formed be-

(I) tween Metal-Substituted Polyoxometalates and Hen Egg White Lyso-

426 zyme

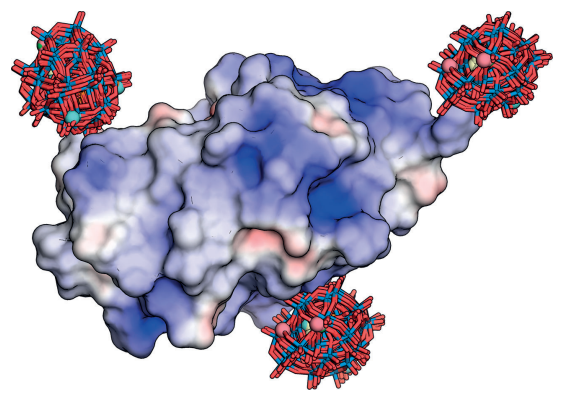

Single crystal X-ray structures of four noncovalent complexes between POMs and HEWL were determined, and the influence of the type of substituted metal on the mode of POM binding to a protein was investigated.

Authors: Please check that the ORCID identifiers listed below are correct. We encourage all authors to provide an ORCID identifier for each coauthor. ORCID is a registry that provides researchers with a unique digital identifier. Some funding agencies recommend or even require the inclusion of ORCID IDs in all published articles, and authors should consult their funding agency guidelines for details. Registration is easy and free; for further information, see http://orcid.org/.

431 Laurens Vandebroek

Yentl Mampaey

Svetlana Antonyuk

Luc Van Meervelt

Tatjana N. Parac-Vogt* 